\title{
Seasonal Migrants and Advocacy:
}

\author{
${ }^{1}$ Dr J. Godwin Premsingh, ${ }^{2} \mathrm{Mr}$ Wesley D Ebenezer \\ ${ }^{I}$ (Associate professor, Bishop Heber College, India) \\ ${ }^{2}$ (PhD - Research Scholar, Bishop Heber College, India)
}

"I have no other option than to migrate to nearby sugar-cane plantation in urban areas... The agriculture here is rain fed and we are left with-out work for about 8 months. Though we face hardships at the plantation... we need to feed our family and so we migrate. I wish I don't have to migrate..."

\section{- $\quad$ (Voice of the vulnerable; Taklipada in Dangs District,Gujarat.)}

The purpose of this study is to understand and voice out the problem faced by seasonal migrant tribals and their children. According to an estimate, nearly one quarter of Asia's poor live in mountain areas. They are rain-fed farmers, forest dwellers, highlanders and indigenous people (UNDP 1997). Similarly, it is estimated that nearly 60 per cent of the world's population live in marginal lands, a large proportion of which are prone to frequent shocks of droughts. Hence, about half of the two million people living in dry land regions are likely to be poor (UNDP 2001). The above evidence suggests a spatial concentration of poverty world over, and the critical importance of mobility.

\section{Advocacy}

The voice of these poor vulnerable minorities is mostly not heard, and therefore the need for advocacy rises. An advocacy campaign is a set of actions targeted to create support for a policy or proposal.Nongovernmental organizations (NGOs) and human rights defenders around the world are working to advocate for the protection of the underprivileged and the minority groups from being discriminated against any kind of fundamental violation of the right to life, liberty and security of person. This paper looks to advocate the exploitive conditions in which the tribals seasonally migrate, who are exploited sugarcane plantation owners.

Advocacy looks to advocate and makes efforts to change policy to practice at the local, national or international level; and to change the situation for groups of individuals as a whole who share similar problems.

\section{Seasonal migration in Gujarat and need for advocacy}

The economy of Gujarat is considered an advanced and dynamic regional economy of the country. It is growing at a consistent rate in the past few decades. As compared to the 80s, economic growth in Gujarat picked up remarkably in the 1990s; the rate increased from 5.7\% to 8.1\% per annum (against the all India rates of $5.6 \%$ to $5.9 \%$ per annum). In fact it was the highest rate recorded amongst the major states (A Kohli, 2006). The state has experienced rapid industrial growth in the post-reforms period (SP Kashyap and D Awasthi, 2005, A Kohli, 2006). Good infrastructure, productive labour force and a prolonged record of pro-business government were the initial advantages that triggered the growth spurt of more than two percentage points in the $90 \mathrm{~s}$ over the $80 \mathrm{~s}$ decade.

However, a major constraint on growth in Gujarat is the poorly endowed natural resources, which are distributed unevenly and also managed inefficiently. Regional variations in rainfall availability are very high, two years in every five are drought years and rainfall is concentrated only in 3-4 months. Most of the rivers are small and seasonal.

The developed irrigation potential is only around $37 \%$ of the cultivated area. Therefore, state is facing severe environmental degradation in several regions. The major problem areas are the desert and semi-desert areas of the north, the saline coastal areas of Kutch and Saurashtra and around the Gulf of Khambat. There is also declining vegetation and soil erosion in the eastern tribal belt from Sabarkantha in the north to Dangs in the south, which is degraded due to deforestation and consequent erosion of soil. This has led to seasonal migration in lean season in search of work for livelihood.

In the southern region of Dangs, there is unavailability of employment through the year leaving the rural poor with no other option than to migrate for employment. This reality also needs to be brought to the fore. There are NGOs lobbying for them, but since not much study has been done on them, it has remained neglected for long and government has done too little. 
a. Study Design

\section{ResearchMethodology}

This is a descriptive study on seasonal migrant tribals. The researcher has attempted to describe the situation of the seasonal migrant tribals and children of Dangs district, Gujarat in detail. It describes the reason for migration, and the exploitation they face as they migrate to sugar cane plantations for harvesting. Further, the social, economic and living condition at the place of migration is also described.

\section{b. Sample Design \\ Population}

The seasonal Migrant tribalcomprise the population size for the purpose of the study.

Unit of Analysis

The tribals who seasonally migrate in Dangs district, Gujarat comprise the unit of analysis for the study.

\section{Sample procedure and Size}

Purposive sampling was adopted. The primary consideration for purposive sampling is that, the researcher only goes to those people who are likely to have required information and are willing to share it. The size of the sample is 50 families.

\section{Analysis Design}

The researcher used descriptive narration to analyse the data. Diagrammatic presentations are also used.

\section{c. Methods of Data Collection}

Primary and secondary data were gathered. The main tool used to collect the primary data was Interview guide. The interview guide enabled the respondents to share the life condition, experiences and was not strictly restricted to the questions. The data collected was qualitative data. The researcher spent time with the migrant for a couple of weeks to understand the problem in detail.

a.

\section{Major Findings}

\section{Seasonal Migrants of Dangs}

The tribals migrate because they need to earn money to support their livelihood. Among them a few voiced that they migrated for food, family care and to support their children. The seasonal migrants also migrate with their children. Almost everyone voiced that they migrate to sugarcane plantation for sugarcane cultivation. The migration cycle as described by the migrants isseen in Fig 1.

\section{Fig 1:}

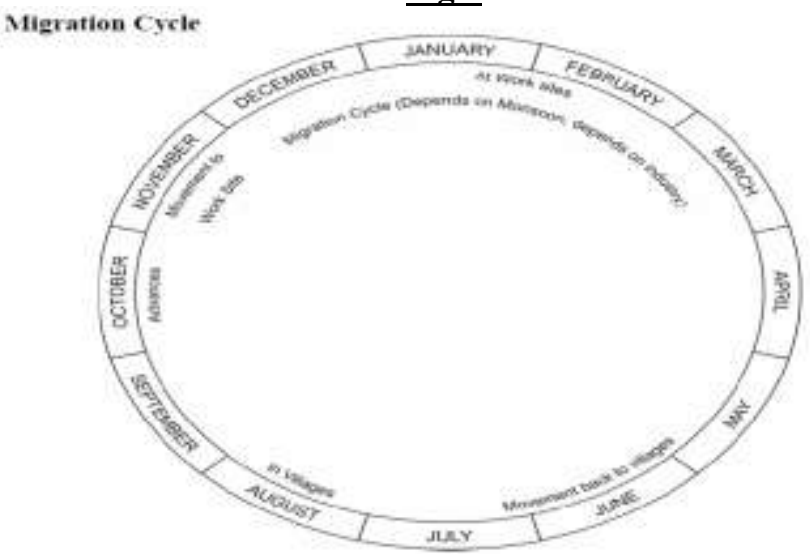

\section{b. Social Condition}

They are placed just besides sugar plantation plain fields or by the river beds in small huts made of tarpoi, bamboo and plastic to protect themselves from rain. The seasonal migrant tribals fight among themselves to occupy a good area of land for stay, in order to have access to river or stream if near-by. The contractors provide them with ration of $25 \mathrm{kgsJavar}$ in every 15 days.

The waste or leftover shoots of sugarcane left in the field are sold by the migrants and their children (migrate along with the parent). By selling these shoots they buy vegetables and thus cook their food.Near-by the working sites in about1-10 kms the contractors arrange for the accessibility to hospital or provide a clinic. 
The living conditions are very bad with no proper drainage and cramped. The land is terrain and uncomfortable to construct tents.

Therefore there is a need for improved living condition and proper health facility for the migrants.

\section{c. Education:}

Small children who migrate with the parents are left in the tents on their own or play around the fields where their parents work. Sometimes young children drop out of school and migrate along with the parents to take care of the little ones. Young boys and girls over the age of 12 or 13 drop out of school, and migrate with their parents to have fun and to roam around. They take up small jobs like collecting shoots and selling them and do the work same as the parent and other works as the elders. But the majority of the parents leave their children in their village to attend school and they migrate. There are few NGOs who run seasonal schools or ashram for the seasonal migrants' children. But proper steps need to be taken toavail the child care and facilities for the school.

\section{d. Health}

During migration the common illness faced are diarrhoea, viral infections, stomach-aches, flu and back-aches. The sugarcane contractors provide a private health clinic where the migrants could avail medical facilities. The migrants need to travel $12-20 \mathrm{kms}$ to avail an urban hospital for their illness. Deaths also occur in the sugarcane plantations because of snake-bites and other accidents. The children are the most vulnerable in this situation.

Proper sanitation facilities also need to be set-up. The accessibility to medical facility also needs to be improved.

\section{e. Work \& Pay}

The sleeping time of the labourers is very rare. They sleep only for one or two hours a day during lunch or dinner breaks. Their timings are very tough. They work round the clock for 21- 24 hours a day. They seasonally migrate for 4-8 months. They need to be available whenever a truck comes to pick up the load. In the sugar plantations the labourers have to harvest the sugarcane and load them in the truck. Every day they fill up 2-3 trucks and 15-16 people work in loading the truck.They should harvest the sugarcane and load the trucks and it takes nearly 8-10 hours to fill one truck. One truck can carry 15 tons of sugarcane. They workers work in pairs. And for every tone the contractor are to be paid 170 rupees per pair. But the contractor pays the migrant $70-80$ rupees per person for a days work.

The migrants' tribals take loans from the contractors and moneylenders, before they leave from their villages for day-to-day expenses or other needs. The moneylenders and contractors give them loan at $50 \%$ interest and subtract the loan in their income; otherwise they are bonded to migrate again to pay-off their loans.

\section{f. Positives and Negatives in migration}

The living conditions and the work are very bad and degrading. They do heavy physical labour all day long without sleep in a hot weather. They are forced to adjust in these conditions as they have to earn money for their needs. The agriculture in their villages in the hills is rain-fed and is seasonal and they migrate to these fields to work out of compulsion.

The only comfort remaining that the tribal are able to earn money and find employment in the lean season.

\section{Recommendation}

It is necessary for Government or Non-governmental Organisation (NGO) to take a few steps to reach out the vulnerable migrants and their children...

1. Establish the necessary conditions for the effective access of seasonal workers to the full respect of equal treatment regarding work conditions, social rights and access to legal redress.

2. The seasonal migrants and their children should have access to basic services likewater supply, shelter and social security.

3. The seasonal migrants and the children need to have access to essential food grain and use ration card at the place of migration.

4. They also need access to child care services such as birth registrations, child care and education for their children.

5. They also need to have access to financial security, savings and proper subsidised loans.

6. Advocating at the state level for policy solutions that will benefit the seasonal migrant and their children.

7. Disseminating information and resources to the seasonal migrant tribals.

8. Stimulating the creation of new health access points and the expansion of medical capacity and services for seasonal migrants. 


\section{Conclusion}

There are not many NGOs and individuals lobbying and advocating to offer decent working conditions and comprehensive social protection measures which are vital to guarantee a standard of rights which is common to all workers, including seasonal workers. Seasonal migration is not a substitute for economic development. Industrial development continues to be highly concentrated in nature and the new investments too are veering towards the existing industrialised regions. There are thus tremendous spatial imbalances in the levels of development. The hill districts where the tribal population resides comprises $15 \%$ of the population yet $43 \%$ of the rural poor in the state are concentrated in this group. These hill districts do not experience trickle down of growth benefits and very little employment or income growth has been witnessed here.

Government need to generate work, where these migrant tribals are not exploited and provide schemes to improve their agriculture in their respective village, so that they don't migrate. The government and the employers of the seasonal migrants need to view seasonal migrant workers not merely as economic units but as human beings; reinforce complaints mechanisms and strengthen rules on labour inspections to monitor the conditions. They also need to provide childcare and educational facilities for the children who migrate along.

\section{Bibliography}

[1] Dev, S.M. (2002) 'Pro-poor Growth in India: What do we know about the Employment Effects of Growth 1980-2000?' Working Paper 161, London: Overseas Development Institute.

[2] Farrington, John and Gill, Gerard J. 2002. 'Natural Resource Perspectives', Paper 79, ODI, May.

[3] Kohli, Atul (2006), "Politics of Economic Growth in India, 1980-2005", Economic and Political Weekly, April 1-7.

[4] UNDP 1997. Human Development Report. New York: Oxford University Press.

[5] UNDP 2001. Human Development Report. New Delhi: Oxford University Press. 